\title{
EL PARÁMETRO DE DILIGENCIA DEBIDA DE LA ADMINISTRACIÓN CONCURSAL EN LA CONFECCIÓN DEL INFORME
}

\author{
César Gilo Gómez \\ Abogado. Doctor en Derecho \\ por la Universidad de Salamanca \\ cesargilo@usal.es
}

\begin{abstract}
RESUMEN
La determinación del nivel de exigencia en la actuación de la Administración Concursal a la bora de confeccionar el informe constituye la cuestión fundamental en el desarrollo de este documento regulado en los arts. 74 y 75 de la Ley Concursal. En este sentido, sólo a través de la fijación del patrón de conducta de los profesionales al afrontar esta tarea podremos establecer hasta dónde llegan los límites de su actuación. Este patrón viene determinado por el deber de diligencia.

Palabras clave: Administración Concursal, informe, parámetro de diligencia, Ley Concursal.

\section{ABSTRACT}

Establishing the level of requirement in the way Administration sees the Process of Bids in order to pen a report makes it the main point in the development of the form regulated in articles 74 and 75 of Bid Act. Abounding on this, it is only through the establishment of the behavioral pattern of professionals when facing this task that it will be able to establish the limits of their performance. Such pattern is clearly linked to the duty of diligence.
\end{abstract}

Keywords: admin Bids, Reports, Duty of Diligence, Bidding Act.

\section{ZUSSAMENFASSUNG}

Die Festlegung des Anforderungsniveaus bei der Ausübung der Berichtstätigkeit der Konkursverwaltung umfasst den Kernpunkt bei der Abfassung der Artikel 74 und 75 des Konkursrechts. In diesem Sinne können die Grenzen der Tätigkeit der Kursverwalter nur bestimmt werden durch eine eindeutige Festlegung eines Handlungsschemas bezogen auf die Ausübung ibrer Tätigkeit. Dieses Handlungsschema wird bestimmt durch die Verpflichtung zur Sorgfaltspflicht.

Schlüsselwörter: insolvenzverwaltung, Bericht, Parameter der Sorgfaltspflicht, Konkursrecht. 
SUMARIO: I. INTRODUCCIÓN.-II. INSTRUMENTOS DELIMITADORES DEL PARÁMETRO DE DILIGENCIA DEBIDA EN LA CONFECCIÓN DEL INFORME.-1. Reducción del número de integrantes de la Administración Concursal.-2. La ayuda de los auxiliares delegados y de los expertos independientes para cumplir con el parámetro de diligencia exigida.-III. ADMINISTRADOR CONCURSAL PERSONA JURÍDICA COMO SOLUCIÓN PARA INTEGRAR EXPERTOS JURÍDICOS Y ECONÓMICOS EN LA ADMINISTRACIÓN CONCURSAL QUE CUMPLAN CON EL PARÁMETRO DE DILIGENCIA EXIGIBLE EN LA ELABORACIÓN DEL INFORME.-IV. LA RELACIÓN DE LA ADMINISTRACIÓN CONCURSAL Y EL DEUDOR PARA CUMPLIR CON LA DILIGENCIA DEBIDA EN LA ELABORACIÓN DEL INFORME.V. LA LABOR VERIFICADORA DE LA ADMINISTRACIÓN CONCURSAL.

\section{INTRODUCCIÓN}

La necesidad de establecer la exigencia requerida en la actuación de la Administración Concursal en el procedimiento concursal obliga a acudir a un parámetro que sirva para determinar hasta dónde alcanzan sus obligaciones. Esta necesidad se pone especialmente de relieve a la hora de fijar las funciones de la Administración Concursal en la elaboración del documento más importante que debe ésta afrontar en el seno de la tramitación del procedimiento judicial: el informe regulado en los arts. 74 y 75 de la Ley Concursal (en adelante, LC). La pregunta que debemos hacernos no es otra, por tanto, que determinar la diligencia exigible al administrador concursal que confecciona el informe y su relación con el deber de diligencia requerido en la generalidad de las relaciones obligacionales ${ }^{1}$.

${ }^{1}$ El deber de diligencia es definido por el art. 1.104 del Código Civil como el comportamiento «que exija la naturaleza de la obligación y corresponda a las circunstancias de las personas, del tiempo y lugar», y sólo en caso de que «la obligación no exprese la diligencia que ha de prestarse en su cumplimiento se exigirá la correspondiente a la de un buen padre de familia». R. SÁnCHEZ ARISTI, «Comentario al art. 1.104», en R. BERCOVITZ RodRÍguez-Cano (coord.), Comentarios al Código Civil, Cizur Menor, Aranzadi, 2001, p. 1284, señala que la diligencia del buen padre de familia, más que un modelo singular, se erige en la clase de todos los modelos de diligencia prestable, atendidas en cada caso la naturaleza de la obligación y las circunstancias de la persona, tiempo y lugar. Añade el autor que el segundo apartado del art. 1.104 CC admite que la obligación exprese otro modelo de diligencia pactado por las partes, es decir, la exigibilidad de un estándar diferente. En igual sentido, B. Rodríguez Rosado, «Comentario al art. 1.104», en AAVV, Código Civil comentado, Cizur Menor, Thomson Reuters, 2011, p. 118, recoge «el estándar de conducta de profesional o perito» entre los elementos que deben tenerse en cuenta a la hora de particularizar el modelo del buen padre de familia, que exige del profesional que desarrolla una actividad que requiere de particulares conocimientos técnicos una actuación adecuada con esos conocimientos, de forma que supondrá una falta de diligencia la inobservancia de la lex artis peculiar de su profesión. Añade que esto no quiere decir que las reglas profesionales o téc- 
En este sentido parece evidente que no es suficiente la diligencia del buen padre de familia propia del Código Civil, sino que, al situarnos en el ámbito profesional, la diligencia exigida en el art. 35.1 LC (diligencia de un ordenado administrador y de un representante leal) constituye un deber de diligencia más elevado y acorde con el que se corresponde con un encargo a un profesional específicamente cualificado para una determinada tarea ${ }^{2}$.

Como premisa general hay que partir de la idea de que la diligencia que es exigible al administrador concursal en el cumplimiento de la principal función que se le encomienda en el procedimiento concursal (la ela-

nicas sean un concepto fijo, puesto que lo mismo que el modelo del «buen padre de familia» requiere de adaptación al caso concreto. Para R. GARCíA PÉREZ, «La diligencia profesional: un concepto clave del nuevo Derecho contra la competencia desleal», Anuario de la Facultad de Derecho de la Universidad de A Coruña, núm. 14 (2010), pp. 23-38, la diligencia profesional es un concepto jurídico indeterminado que se complementa conforme a las exigencias.

2 Así lo entiende también C. MuÑoz de BENAVIDES, «La responsabilidad de los administradores concursales», Diario La Ley, núm. 7522, Sección Tribuna, año XXXI, ref. D-369, 2 de diciembre de 2010. La diligencia exigible es superior a la de un administrador social, puesto que el administrador concursal es un profesional nombrado legalmente por su especial cualificación para desarrollar una importante y compleja tarea, mientras que el administrador social es nombrado de acuerdo a las reglas del libre comercio y sus decisiones, más allá de si son acertadas o no, deben entenderse en este contexto (a diferencia del administrador concursal quien debe ser mucho más conservador en sus decisiones, ajustándose en todo caso al marco legal que preside su actuación). En este sentido vid. F. MARTínez SANZ, «Responsabilidad civil y penal de los administradores concursales», ADC, núm. 31 (2014), p. 68, quien señala que el estándar o patrón de conducta exigible al administrador concursal no es el del «ordenado empresario» del art. 225 LSC, sino que debe ser un «ordenado administrador», añadiendo el autor que éste es un cambio lógico toda vez que el administrador concursal es, ante todo, gestor o administrador de la masa. F. JuAn y MATEU, «Comentario al art. 35», en A. Rojo y E. Beltrán (coords.), Comentario de la Ley Concursal, t. I, Madrid, Civitas, 2004, p. 709, destaca que no se exige de ellos el grado de diligencia que permitan las singulares capacidades y conocimientos que poseen, sino el que desplegaría un administrador concursal prototípico, teniendo en cuenta las circunstancias del caso concreto y la consciencia social sobre el trabajo que debe desarrollar este profesional. J. QUIJANO GoNZÁLEZ, «La responsabilidad de los administradores concursales», en AAVV, Estudios de Derecho de sociedades y Derecho concursal. Libro homenaje al profesor Rafael García Villaverde, t. III, Madrid, Marcial Pons, 2007, p. 2081, resalta que nos encontramos ante una modalidad de cumplimiento de los deberes legales que la Ley impone al administrador concursal. Por último, destacamos el pronunciamiento de la STS (Sala 1.a) de 4 de febrero de 1992 (rec. 2618/1989), relativo a la exigencia de un mayor grado de diligencia a los abogados respecto al parámetro del buen padre de familia, y la SAP Córdoba (Sección $3{ }^{a}{ }^{a}$ ) de 7 de julio de 2008 (rec. 159/2008), que en su fundamento de Derecho tercero establece sobre este particular: «Se trata, por consiguiente, de valorar la actuación de la Administración Concursal bajo el prisma de este doble rasero: qué hubiera hecho un ordenado administrador y un representante leal en el caso concreto enjuiciado, cómo hubiera debido cumplir la obligación legalmente impuesta, qué comportamiento hubiera debido observar en ausencia de previsión legal expresa y qué era lo exigible conforme a dichos parámetros». 
boración del informe) debe ser la diligencia propia que se le requiere a un profesional conocedor de la materia concursal y cualificado para actuar en referido procedimiento. Por esta razón no es suficiente con que el profesional o los profesionales que integren la Administración Concursal sean simplemente expertos titulados en la rama que desempeñan, debido a que la confección del informe de los arts. 74 y 75 LC, al ser un completo estudio jurídico y económico del pasado, presente y futuro del deudor, exige que los profesionales que conforman la Administración Concursal tengan un plus de preparación acorde a la labor que deben desarrollar. En este sentido, el margen de negligencia que puede permitírsele a estos profesionales es muy reducido 3 , ya que la Ley demanda el nombramiento como miembros de la Administración Concursal de personas especialistas en la disciplina concursal, bien sea en la rama jurídica o en la económica. Es equivocado pensar que un profesional jurídico o económico, con importantes conocimientos en su materia, está facultado para desempeñar el puesto de administrador concursal y poder confeccionar un documento tan especial como es el informe, puesto que deben ser profesionales que, además de su preparación jurídica o económica de base -ello se supone-, tengan un conocimiento amplio de la materia concursal para poderse enfrentar con garantías a la tramitación de un procedimiento como ante el que nos encontramos.

El grado de diligencia exigible en este sentido no es el de un abogado o un economista, sino el de un abogado o economista conocedor de la materia concursal ${ }^{4}$. La Ley está exigiendo que se nombren profesiona-

3 De hecho, de los tres tipos de culpa admitidos en nuestro ordenamiento civil (culpa grave o lata, culpa leve o culpa levísima) un criterio de imputación basado en la culpa leve sería suficiente para imputar responsabilidad a la Administración Concursal, ya que el art. 36 LC simplemente habla de culpa o negligencia. Ello es consecuente además con la labor encomendada a la Administración Concursal, quien al encargase de una tarea tan específica tiene un margen de negligencia mínimo. En este sentido vid. J. FERRÉ FALCÓN, «Administración Concursal», en AAVV, Comentarios a la reforma de la Ley Concursal, Madrid, CISS, 2010, pp. 44 y 45, donde se recoge que, a diferencia de los funcionarios públicos cuando ejercitan labores de Administración Concursal quienes sólo responden por culpa grave o dolo, la Administración Concursal profesional responde por la mera culpa o negligencia.

${ }^{4}$ Destacamos la completa exposición que realiza de la diligencia exigible al órgano de Administración Concursal el profesor TIRADO. A pesar de que la obra es anterior a la reforma del art. 27 LC que se produjo en el año 2011 en lo relativo a la formación que se le exigía a los profesionales en materia concursal (momento en el que sólo se requería simple compromiso de formación), el autor señala que la Ley presume que los profesionales nombrados tienen la capacidad necesaria para realizar las funciones propias del cargo. Vid. I. TIRADO, Los administradores concursales, Cizur Menor, Thomson Civitas-Aranzadi, 2005, pp. 135-157. 
les cualificados, especialistas en materia concursal y que puedan afrontar con garantías la resolución de los problemas que a buen seguro planteará la tramitación del procedimiento concursal, ya que no olvidemos que el art. 27.1 LC exige formación especializada en Derecho concursal ${ }^{5}$.

En lo estrictamente concerniente al informe, la Ley requiere a profesionales que puedan afrontar sin problemas la confección de un documento técnico-jurídico y económico esencial para la tramitación del procedimiento judicial, que va a producir importantes efectos patrimoniales en una pluralidad de personas y que está compuesto por distintas partes ensambladas entre sí que exigen del profesional encargado de su confección el mayor grado de diligencia posible en la elaboración de cada una de ellas, lo que puede requerir, dependiendo del análisis que deba efectuarse en cada una de las partes, el apoyo o no en otros profesionales para que el patrón de diligencia exigible no se vea afectado. Por ello, el parámetro de diligencia que se exige es el propio de un profesional con conocimientos en la materia concursal y que es precisamente lo que lleva a éste a apoyarse en otros profesionales para el desarrollo de aquellas partes del informe en las que el grado de diligencia en la confección del mismo disminuiría de no acudir a ellos.

\section{INSTRUMENTOS DELIMITADORES DEL PARÁMETRO DE DILIGENCIA DEBIDA EN LA CONFECCIÓN DEL INFORME}

Determinado el régimen de nombramiento, parece oportuno analizar a continuación aquellos aspectos que influyen en la configuración del parámetro de diligencia debida con el que debe actuar la Administración Concursal.

\section{Reducción del número de integrantes de la Administración Concursal}

En primer lugar, hacemos referencia a la evolución del número de integrantes de la Administración Concursal producida a raíz de las modificaciones del texto normativo a lo largo de los años de vigencia de la Ley.

\footnotetext{
${ }^{5}$ En otros ordenamientos como el alemán ( $\$ 56$ InsO) debe ser un experto en negocios.
} 
En este sentido, la Exposición de Motivos de la Ley 38/2011, de Reforma de la Ley Concursal, señala en su punto VII que, consciente de la importancia del papel de los administradores concursales, se busca una mayor profesionalización de los mismos, potenciando sus funciones y requisitos a través de dos mecanismos: el administrador concursal único para la generalidad de los supuestos y el reconocimiento de la persona jurídica como administrador concursal.

Por ello, no podemos obviar un hecho esencial y que influye de forma fundamental en la confección del informe, esto es, la reducción del número de administradores concursales nombrados para la generalidad de los concursos, que ha pasado de tres a uno tras la reforma introducida por la Ley $38 / 2011^{6}$.

Partiendo de esta situación, la confección del informe de la Administración Concursal recae ahora, en vez de en tres profesionales, en uno sólo en la gran mayoría de los casos. Esta situación es fruto de una progresiva evolución de la Ley en esta materia a raíz de las reformas operadas. Ya en el año 2009 se tomó la decisión de aumentar el umbral del pasivo determinante para acudir al procedimiento abreviado previsto en la Ley, procedimiento que desde su configuración en el año 2003 preveía el nombramiento de un solo administrador concursal. En este estado de cosas, la redacción del año 2003 señalaba que el juez podía acordar acudir al procedimiento abreviado siempre que la estimación inicial del pasivo no superase el millón de euros. Pues bien, como ya hemos visto, la reforma del año 2009 aumentó la estimación inicial del pasivo a diez millones de euros, permitiendo que el margen en el que se aplicara el procedimiento abreviado y, por ende, el nombramiento de un único administrador concursal aumentase. La continuidad en el espíritu reformista se produjo con la reforma del año 2011, donde se cambió la estructura original de nombramiento de tres administradores concursales, salvo excepciones. Ahora la regla general ha pasado a ser el nombramiento de un único administrador concursal y la excepción la configuran los concursos de especial trascendencia ${ }^{7}$.

${ }^{6}$ Como veremos a continuación, la Ley prevé también la posibilidad del nombramiento de personas jurídicas que realicen la función de administradores concursales, siendo necesario que exista en su seno al menos un abogado y un economista. En este caso estaríamos ante el nombramiento de una organización compuesta por profesionales jurídicos y económicos que actúan bajo una misma forma jurídica.

7 Estos procedimientos han venido siendo, según la redacción del año 2011, aquellos cuya cifra de negocios sea igual o superior a cien millones de euros, o bien que la masa pasiva sea superior a cien millones de euros, que el número de acreedores supere los mil o que el 
Realmente la Ley ha acabado de forma drástica con la Administración Concursal trimembre originaria que nació en 2003. El hecho de que se conserve el nombramiento de dos administradores concursales para determinados concursos no quiere decir que se respete la estructura que existía, puesto que para este tipo de concursos lo que se prevé es nombrar a un administrador profesional ${ }^{8}$ que será sobre el que recaiga el gran peso de la llevanza del concurso y un administrador concursal acreedor que no tendrá ni mucho menos igual relevancia —aunque sí estará sometido al mismo régimen de responsabilidad que el primero-. Solución legislativa ésta que no se alcanza a entender, ya que para el caso de concursos de especial complejidad, con todo lo que ello conlleva en cuanto a las importantes cifras de negocios, número de acreedores y número de trabajadores, la única solución aportada por el legislador es aumentar la composición de la Administración Concursal nombrando un administrador concursal acreedor que ni siquiera ostentará la representación de la Administración Concursal frente a terceros.

Entendemos razonable la postura relativa a aumentar los medios de los que dispone la Administración Concursal al encontrarnos ante concursos de especial complejidad o trascendencia, debiendo ser obligatorio apoyarse en más profesionales que ayuden en la confección del informe (auxiliares delegados o expertos independientes) y que se conceda la posibilidad de obtener mayores prórrogas para la elaboración del mismo.

El legislador opta, sin embargo, por añadir un administrador concursal más que deberá ser nombrado entre acreedores ${ }^{9}$ titulares de créditos

número de trabajadores sea superior a cien. Para estos casos serán nombrados dos administradores concursales, quedando con esta reforma el procedimiento abreviado reservado para deudores con pasivo no superior a cinco millones de euros. Sin embargo, la Ley 17/2014, de 30 de septiembre, ha suprimido el art. 27 bis LC que hacía referencia a los concursos de especial trascendencia, incorporando al art. 27.4 LC la previsión relativa a que reglamentariamente se desarrollará qué se entiende por concurso de tamaño pequeño, medio y grande. Como hemos venido destacando, según lo establecido en la disposición transitoria segunda de la Ley 17/2014, la reforma de este artículo no entrará en vigor hasta que no se apruebe su desarrollo reglamentario, lo que produce que en la práctica nos encontremos con que los concursos de especial trascendencia a efectos de designación de la Administración Concursal siguen todavía vigentes, pero el artículo que los regulaba (art. 27 bis LC) ha sido ya suprimido. Esta evidente descoordinación de preceptos hubiese sido fácilmente salvable simplemente con hacer coincidir la supresión del art. 27 bis con la entrada en vigor del nuevo art. 27 LC.

${ }^{8}$ Según el art. 27.2.3..$^{\circ} \mathrm{LC}$ es éste quien ostenta la representación de la Administración Concursal frente a terceros.

9 Por el tenor de la Ley, parece que es el juez el que decidirá qué concreto acreedor ejerce la labor de administrador concursal. Nada se dice sobre la posibilidad de que el acreedor 
ordinarios o con privilegio general no garantizado de entre los que figuren en el primer tercio de mayor importe ${ }^{10}$, adoptando de esta forma una solución legislativa que rompe con el modelo profesional establecido en la Ley ${ }^{11}$. Realmente este administrador concursal acreedor no aporta nada al procedimiento y es una figura que debería eliminarse por ser juez y parte en el procedimiento, ya que no debemos olvidar que el profesional designado como administrador concursal acreedor representa al acreedor por quien ha sido nombrado, por lo que no parece descabellado pensar que pueda actuar en interés de su representado ${ }^{12}$.

Por todo ello, por su escasa relevancia de cara a la confección del informe, por no ejercer siquiera representación alguna de la Administración Concursal, por no representar a los acreedores y tener, por el contrario, interés particular, rechazamos la figura y proponemos su eliminación de la Ley ${ }^{13}$.

designado no acepte y las consecuencias que ello tendría, además de qué ocurriría si ninguno de los acreedores que reúnen las condiciones para ser designado administrador concursal acreedor quiera aceptarlo.

${ }^{10}$ Es de sumo interés en este sentido la SAP Madrid (Sección 28. ${ }^{a}$ ) de 7 de marzo de 2014 (rollo núm. 435/2013), en cuya parte dispositiva se declara que el administrador concursal acreedor nombrado en el procedimiento no reunía las condiciones para ser elegido, al ser la sociedad designada titular de créditos garantizados con prenda en el procedimiento, lo que supone la infracción del art. 27.2.3. ${ }^{\circ} \mathrm{LC}$. De igual forma, destacamos el pronunciamiento contenido en la SJMer de Bilbao núm. 1, de 2 de octubre de 2009 (incidente concursal núm. 457/2009), que recoge que si el administrador concursal acreedor que fue designado en un primer momento con la declaración de concurso, al emitirse el informe de la Administración Concursal se comprueba que ha dejado de cumplir las condiciones subjetivas previstas para su nombramiento, no podrá continuar ostentado este cargo y deberá ser cesado.

${ }^{11}$ La idea de que uno de los integrantes de la Administración Concursal fuese un acreedor surge con la composición tradicional trimembre de la Administración Concursal, donde se buscaba dar representatividad a los acreedores en el órgano técnico del concurso - lo cual tampoco tenía mucho sentido dado que las decisiones se tomaban por mayoría y ésta podía alcanzarse simplemente con el voto de los dos profesionales designados-, pero en la situación actual, donde se pretende que con el nombramiento de este administrador concursal acreedor se ayude de alguna manera al profesional designado para el cargo, no entendemos que se siga manteniendo la figura. Además, recayendo el nombramiento del administrador concursal acreedor en el juez del concurso y no en los propios acreedores, no va a cumplirse con la función de representatividad buscada en la Exposición de Motivos de la Ley.

${ }^{12}$ Exponen perfectamente la situación R. Villarín Vinent y J. A. Martín Blázquez, «La vinculación del administrador concursal acreedor y el profesional nombrado para el ejercicio del cargo», RDCP, núm. 17 (2012), p. 265, quienes entienden que parece un descuido del legislador, ya que en el devenir del proceso legislativo se eliminó por error las referencias a la designación profesional por el administrador acreedor persona natural sin estar previsto.

${ }^{13}$ En igual sentido P. Martínez Espín, «Comentario al art. 32», en R. BerCovitz RodríGuez-Cano (coord.), Comentarios a la Ley Concursal, t. I, Madrid, Tecnos, 2004, p. 262, 
Otro argumento más a favor de la erradicación de la figura lo constituye el apartado $c$ ) del art. 28.1 LC, donde se regula el régimen de incapacidades, incompatibilidades y prohibiciones de los miembros que forman la Administración Concursal. En este precepto se recoge expresamente que no podrán ser nombrados administradores concursales quienes, en función de lo establecido en la Ley de Auditoría de Cuentas ${ }^{14}$, tengan relación con un acreedor que represente más del 10 por 100 de la masa pasiva del concurso. Parece inconcebible, por tanto, que se permita la elección de un acreedor como administrador concursal que, según el art. 27.2.3. ${ }^{\circ} \mathrm{LC}$, debe figurar entre los que se sitúen en el primer tercio de mayor importe de los créditos ordinarios o con privilegio general no garantizado, ya que es presumible que su porcentaje en la masa pasiva sea importante ${ }^{15}$.

Ciertamente, la Ley no señala que obligatoriamente el acreedor designado como administrador concursal tenga que elegir a un profesional que le represente, pero, aunque no fuese representado por ningún profesional, la objetividad de este acreedor sería igualmente cuestionable, lo que nos lleva a rechazar esta figura.

Una vez analizada la evolución de la Ley en cuanto al número de profesionales se refiere y la composición actual, debemos establecer los efectos de la referida evolución en relación al procedimiento. Del examen de la Exposición de Motivos de la Ley 38/2011, de Reforma Concursal, que introdujo la modificación de la composición del órgano a un administrador concursal para la generalidad de los casos, comprobamos como el legislador busca que el procedimiento sea ágil y lo menos costoso posible. Estos objetivos aplicados en sede de la Administración Concursal permite explicar la reducción de miembros de la misma, ya que se consigue una mayor agilidad en la toma de decisiones del órgano técnico del concurso, pues es evidente que son más rápidas las decisiones cuando un órgano es unipersonal a cuando el mismo funciona de forma colegiada. De igual forma, no

subraya que, a pesar de las críticas que abogan por una sindicatura profesional, la Ley Concursal, consciente del escaso protagonismo del acreedor en la práctica del órgano de Administración Concursal y del habitual absentismo, más preocupado por el cobro de su crédito que por los intereses colectivos, lo mantiene.

${ }^{14}$ El art. 18 del RDL 1/2011, de 1 de julio, por el que se aprueba el texto refundido de la Ley de Auditoría de Cuentas, señala cuándo se considera que un auditor de cuentas no goza de la suficiente independencia en el ejercicio de sus funciones respecto a la entidad auditada.

${ }^{15}$ La SAP Madrid (Sección 28. ${ }^{a}$ ) de 17 de mayo de 2007 (rollo núm. 124/2007) recoge que para poder tener éxito la vía de la recusación por interés en el asunto, el administrador concursal acreedor tiene que tener un plus relevante respecto al interés normal que todo administrador concursal que ostenta la condición de acreedor tiene. 
podemos obviar que la reducción de administradores concursales conlleva una evidente disminución de costes, puesto que la masa del concurso sólo tendrá que afrontar la retribución de un único administrador en vez de la de los tres previstos originariamente.

Sin embargo, la reducción del número de administradores concursales que intervendrán en el procedimiento trae consigo una polarización de la figura del administrador concursal letrado y el administrador concursal economista. Antes de la reforma, como la Administración Concursal debía estar formada por un administrador concursal letrado y por un administrador concursal economista (además del administrador concursal acreedor), evidentemente cada profesional se encargaba de la rama del informe acorde con su preparación (el letrado se encargaba de las cuestiones jurídicas y el economista de las cuestiones económicas). Este reparto ha quebrado en la actualidad, puesto que al encontrarnos ante un solo administrador concursal, el mismo deberá dedicarse tanto a las cuestiones jurídicas como a las económicas, sea cual sea su especialidad. Ello no obstante, para nada altera el parámetro de diligencia debida en la confección del informe, para el que se sigue exigiendo la misma tanto en la parte económica como en la parte jurídica, siendo ahora más necesario que nunca el apoyo en auxiliares delegados y expertos independientes.

\section{La ayuda de los auxiliares delegados y de los expertos independientes para cumplir con el parámetro de diligencia exigida}

Como hemos venido poniendo de relieve, con la reducción a un solo administrador de la composición del órgano de la Administración Concursal nos encontramos ante situaciones como que un administrador concursal letrado tenga que analizar en el informe magnitudes para las cuales pudiera no estar capacitado y viceversa, es decir, que un administrador concursal economista tenga que analizar en el informe magnitudes cuya formación no le posibilita resolver. La Ley prevé el nombramiento de un experto en materia jurídica o económica en los supuestos de Administración Concursal única, sin exigirse la concurrencia de ambas disciplinas en el mismo profesional, pero ello no quiere decir que al profesional nombrado para el cargo no se le exija la confección de un informe conforme al parámetro de diligencia debida, sino que en el supuesto de que el referido profesional no disponga de los conocimientos necesarios para poder desempeñar la labor encomendada con total eficacia, deberá apoyarse en 
otros profesionales que sí los tengan para suplir de este modo sus carencias y poder cumplir con su cometido.

En este estado de cosas, la figura de los auxiliares delegados y los expertos independientes se erige como la solución a la situación descrita, puesto que con su nombramiento se complementarían las exigencias del profesional nombrado como administrador concursal. Para que este régimen sea efectivo se exigirán las responsabilidades oportunas a los administradores concursales que no se apoyen en estos profesionales y realicen informes evaluando materias que exceden de sus conocimientos. En este sentido, el profesional que acepta el cargo debe ser consciente de que si únicamente es un experto jurídico o económico, deberá contratar con cargo a su retribución a profesionales de la rama de la que carece de conocimientos para poder cumplir con la confección del informe, puesto que el parámetro de diligencia exigible en las diferentes partes de las que se compone el informe es el propio de un profesional con conocimientos jurídicos y económicos —además de conocedor de la materia concursal-.

Hacemos referencia a que los auxiliares delegados y los expertos independientes son figuras profesionales introducidas por el legislador para ayudar a la Administración Concursal en el desarrollo de sus funciones. Es importante no confundir al experto independiente que la Administración Concursal pudiere contratar con los auxiliares delegados. La principal diferencia entre los auxiliares delegados y los expertos independientes es precisamente su régimen de dependencia, mientras que los primeros dependen de la Administración Concursal, los segundos son completamente independientes.

\section{Auxiliares delegados}

Los auxiliares delegados están expresamente previstos en la Ley en su art. $31 \mathrm{LC}^{16}$. Esta figura se ha venido concibiendo como profesionales que puedan ayudar a la Administración Concursal en el ejercicio de la función que tiene ésta encomendada. La figura que prevé el legislador es la de técnicos que, ante concursos de especial complejidad, sea propuesto su nombramiento por parte de la Administración Concursal y aceptado por el juez

16 Cambio de numeración introducido por la reforma producida a raíz de la Ley 17/2014, de 30 de septiembre. El artículo que regula los auxiliares delegados en la Ley Concursal pasa del 32 al 31. 
para asumir parte de la carga de trabajo que conlleva el desarrollo de la función de la Administración Concursal ${ }^{17}$.

Nos encontramos ante personal que ayuda al administrador concursal a desarrollar tareas inherentes a su cargo ${ }^{18}$. Como anticipábamos, a diferencia de los expertos independientes, los auxiliares delegados dependen de la Administración Concursal, que es quien los propone y a los que también retribuye.

Sin pretender agotar la materia, destacamos que la relación con la Administración Concursal puede encuadrarse bajo una multitud de formas jurídicas (relación laboral, mercantil, civil...), si bien es importante hacer referencia a que la Ley no exige forma alguna, es decir, que este tipo de profesionales pueden aparecer vinculados a la Administración Concursal simplemente utilizando como nexo la designación en el marco de un procedimiento concursal, sin ningún tipo de vinculación más.

Dentro del procedimiento y aun no existiendo relación jurídica subyacente alguna, al ser el juez el que, a tenor del art. 31 LC, autoriza su nombramiento, fija sus funciones y su retribución (corriendo, eso sí, la misma a cargo de la Administración Concursal), situamos la relación bajo la figura de la delegación ${ }^{19}$, en la que una de las partes (Administración Concur-

${ }^{17}$ El nombramiento de los auxiliares delegados corresponde al juez del concurso, pero la elección de los mismos es una decisión que toma la Administración Concursal. Por esta razón, en el supuesto de que los auxiliares delegados tengan que responder por actuaciones negligentes en el ejercicio de la función que se les encomienda en el procedimiento concursal, los administradores concursales responderán solidariamente con ellos, en aplicación de la institución de la culpa in eligendo y de la culpa in instruendo, salvo que prueben haber empleado toda la diligencia debida conforme a lo recogido en el art. 36 LC. De igual forma, la Administración Concursal debe supervisar la actuación de los auxiliares delegados que hayan sido nombrados, por lo que puede surgir su responsabilidad también por la vía de la culpa in vigilando.

${ }^{18} \mathrm{La}$ ayuda puede consistir en asumir parte de la carga de trabajo encomendada a la Administración Concursal o en complementar la actuación de ésta cuando el profesional que ostenta el cargo de administrador concursal carezca de conocimientos jurídicos o económicos. Particularmente en lo relativo a la confección del informe, puede ser esencial para la Administración Concursal contar con profesionales que le ayuden a afrontar las diferentes partes de las que se compone el informe para que el mismo sea un estudio jurídico y económico acertado. Esta ayuda extra a los administradores concursales no debe confundirse con la aportación puntual que pudiese proporcionar un experto independiente, quienes sólo intervienen en el procedimiento, a tenor del art. $83 \mathrm{LC}$, para efectuar la valoración de los bienes y derechos del concursado y para valorar jurídicamente la viabilidad de las acciones de reintegración; tareas circunscritas en todo caso al informe de la Administración Concursal, a diferencia de las labores que puede desarrollar un auxiliar delegado, quienes tienen un ámbito de actuación mucho más amplio y que puede desempeñarse a lo largo de todo el procedimiento.

${ }^{19}$ En igual sentido vid. I. Tirado, «Comentario al art. 32», en A. Rojo y E. BeL- 
sal) abona una cantidad económica a la otra parte (auxiliar delegado) para que lleve a cabo una serie de funciones. Parece difícil considerarlos como simples empleados al servicio de la Administración Concursal, puesto que su función es específica y determinada dentro del procedimiento (a pesar de que pueden ser nombrados para una multitud de funciones), además de que el legislador ya contempla la figura de los empleados al servicio de la Administración Concursal en el art. 31.4 LC 20.

Sin perjuicio de lo expuesto, lo habitual en la práctica es que se recurra a la figura del auxiliar delegado cuando se necesite encomendar formalmente a otros profesionales parte de las funciones de la Administración Concursal - como puede ser el mantenimiento de reuniones con diferentes acreedores en nombre de la Administración Concursal- y no para el desarrollo puntual de determinado trabajo, ocasiones en las que se suele acudir a otras fórmulas menos rígidas como es el apoyo en profesionales con los que se pudiese colaborar ${ }^{21}$, figura que aparece reconocida por el legislador en el apartado 4 de este art. 31 como personal al servicio de la Administración Concursal ${ }^{22}$.

TRÁN (coords.), Comentario de la Ley Concursal, t. I, Madrid, Civitas, 2004, p. 659. Para P. MARTínez EsPín, «Comentario al art. 32», op. cit., p. 296, lo que está claro es que no es un empleado al servicio del órgano de la Administración Concursal.

20 E. Gallego SÁnchez (coord.), «Comentario al art. 75», en Ley Concursal. Comentarios, jurisprudencia y formularios, vol. I, Madrid, La Ley, 2005, pp. 389 y 390, puntualiza que debe recordarse que los auxiliares delegados no se insertan en la estructura orgánica de la Administración Concursal y tampoco asumen una función orgánica en el concurso.

${ }^{21}$ Vid. E. Valpuesta Gastaminza, «Comentario al art. 32», en F. Cordón Moreno (dir.), Comentarios a la Ley Concursal, t. I, 2. ${ }^{a}$ ed., Cizur Menor, Thomson Reuters-Aranzadi, 2010, p. 429, quien de forma brillante explica la problemática actual en cuanto al régimen de los auxiliares delegados señalando que: «En realidad, si el administrador precisa un "ayudante", éste preferirá estar ligado a tal administrador por una relación de servicios y no someterse a todo el complejo sistema de incapacidades y, sobre todo, de responsabilidad propio de esta norma. El hecho de ser "auxiliar delegado" no favorece o añade nada a dicha persona, tampoco ahorra coste alguno a la administración y, además, no existe libertad para el nombramiento ni la fijación de la retribución. Por eso, en cierta forma a ninguna de las partes, administración o administrador y "auxiliar material", les merece la pena encauzar la ayuda bajo la cobertura de "auxiliar delegado"».

22 Situación representativa de esta figura en la práctica sería el siguiente ejemplo: un despacho de abogados donde el titular del mismo se encuentra incluido en la lista de administradores concursales del decanato de un determinado juzgado. Si este profesional fuese nombrado como administrador concursal de una persona física o jurídica, muy probablemente se apoyaría en el resto de profesionales que integran su despacho para la tramitación del procedimiento concursal, en vez de acudir a la contratación de un auxiliar delegado a través del juzgado. No obstante, que esta práctica esté generalizada no quiere decir que sea correcta. Véase que la actuación de los auxiliares delegados está sometida al mismo régimen de incapacidad, incompatibilidad, prohibiciones y responsabilidad que la Administración Concursal. Si nos encontramos ante auxiliares delegados «de hecho» y no «de derecho», 
La Ley prevé que en los supuestos de administrador concursal único se podrá designar, previa audiencia del propio administrador concursal, un auxiliar delegado que ostente la condición profesional que éste no tenga. El legislador se refiere con ello a los supuestos en los que el administrador concursal único sea un letrado o un economista y necesite la ayuda de un profesional con conocimientos en la materia de la que éste no es conocedor, materia jurídica o económica según los $\operatorname{casos}^{23}$. Lo que hace el legislador es introducir la posibilidad de que el juez, en los supuestos de Administración Concursal única y en atención a las circunstancias especiales que rodeen el caso, pueda consensuar con el administrador concursal la posibilidad de nombrar un auxiliar delegado ${ }^{24}$. En esta primera parte del art. 31.1 LC nos encontramos ante una mera recomendación del juez del concurso, no una imposición.

Cuestión diferente es la que se regula en la segunda parte del art. 31.1 LC. Aquí el legislador, ante la concurrencia de una serie de circunstancias $^{25}$, faculta al juez del concurso para obligar a la Administración Concursal (tanto persona jurídica como física y tanto en los supuestos de órgano unipersonal como en los supuestos de órgano bimembre, pues no realiza distinción alguna la Ley para los supuestos de nombramiento obligatorio) a nombrar al menos a un auxiliar delegado.

La idea del legislador es que, ante las especiales circunstancias que rodean a un concreto procedimiento concursal y que lo hacen presumiblemente más complicado o con una mayor carga de trabajo ${ }^{26}$, obliga directa-

este régimen nunca podrá entrar en funcionamiento, ya que los referidos profesionales no existen a ojos del concurso, por lo que, de producirse un daño a la masa del concurso o al patrimonio de los acreedores, no se podrá ir contra éstos, sino sólo contra el administrador concursal, lo que supone un problema para los acreedores de cara a exigir responsabilidades. Además de ello, debe tenerse clara la responsabilidad que contraería el administrador concursal por esta forma de actuar (responsabilidad de tipo laboral, en el supuesto de que la tarea encomendada al personal asalariado que tiene a su servicio exceda de sus funciones o su horario de trabajo, y fiscal, si la remuneración de estas personas por esta tarea no fuera declarada a la Hacienda Pública).

23 Vid. L. E. López MÁÑEZ, «Administración Concursal y auxiliares delegados tras la reforma de la Ley 22/2003», RDCP, núm. 16 (2012), p. 143, quien señala que la razón de ser estriba en la necesidad de contar con un profesional del área económica o jurídica cuando el administrador unipersonal lo es del área contraria.

${ }^{24}$ El legislador no recomienda la contratación de auxiliares delegados cuando el administrador concursal sea una persona jurídica, ya que en esos casos se presume que cuenta en su equipo con mayor personal.

25 Estas circunstancias son: empresas con establecimientos dispersos por el territorio, empresas de gran dimensión, cuando se solicite prórroga para la emisión del informe y en concursos conexos en los que se haya nombrado una Administración Concursal única.

${ }^{26}$ F. Juan y Mateu, «La Administración Concursal», en F. Martínez Sanz (dir.), Trata- 
mente al administrador concursal para que nombre al menos a un auxiliar delegado que le ayude en su tarea. Nos encontramos ante una importante incoherencia de la norma que choca con el parámetro de diligencia debida en el desarrollo de la función de la Administración Concursal, ya que ésta desempeña su trabajo con arreglo a los principios de responsabilidad e independencia, debiendo ser la propia Administración Concursal la que como órgano técnico profesional analice la situación ante la que se encuentra y decida qué necesita según su criterio para cumplir con el encargo que se le encomienda ${ }^{27}$, y en caso de que no actúe diligentemente deberá responder por su negligente actuación ${ }^{28}$. Y es que el órgano técnico concursal no necesita que el juez le obligue a nombrar a otros profesionales en caso de encontrarse ante circunstancias que produzcan que el procedimiento al que se enfrenta sea especialmente complicado, sino que será la propia Administración Concursal la que demandará la contratación de los mismos porque el parámetro de diligencia que preside su actuación así se lo requiere, no por un mandato legal.

En este sentido, de las cuatro circunstancias recogidas en el precepto que obligan a la Administración Concursal a nombrar auxiliar delegado ${ }^{29}$ discrepamos expresamente con la obligación de nombrar auxiliares delegados en los supuestos de solicitud de prórroga del informe de la Administración Concursal. Ello porque no olvidemos que es evidente que la solicitud de prórroga se realiza precisamente como remedio para poder cumplir con la confección del informe en plazo, por lo que puede ser innecesario que además haya que nombrar un auxiliar delegado. Tendría sentido su nombramiento antes de la solicitud de prórroga, pero no después de haber pedido la misma ${ }^{30}$.

do práctico de Derecho concursal, Madrid, Tecnos, 2012, p. 218, señala que los presupuestos para el nombramiento obligatorio de auxiliares delegados se darán a menudo en los «concursos ordinarios de especial trascendencia».

27 Vid. J. Quijano González, «La Administración Concursal», en J. Pulgar EzQuerra (dir.), El concurso de acreedores, Madrid, La Ley, 2012, p. 224, donde se señala que la obligatoriedad y el automatismo que prevé la Ley en este nombramiento debe interpretarse utilizando razonablemente la analogía para resolver con coherencia esta cuestión.

${ }^{28} \mathrm{La}$ responsabilidad de la Administración Concursal podrá venir en este sentido por no apoyarse en auxiliares delegados cuando se demuestre que, como consecuencia de ello, se han irrogado una serie de daños a la masa del concurso o a los patrimonios del deudor, acreedores o interesados que podrían haberse evitado si hubiese procedido a la contratación de los referidos profesionales.

29 Vid. C. Romero SAnZ De MAdrid, «Los órganos del concurso», en Derecho Concursal, 2. ${ }^{a}$ ed., Cizur Menor, Thomson Reuters, 2012, p. 114, quien califica los supuestos contemplados en la Ley como «harto imprecisos».

${ }^{30}$ Esta obligación de nombrar auxiliares delegados que se prevé en el art. 32 LC puede 
Por ello, entendemos que este precepto debe ser modificado en el sentido de que se diese la posibilidad al administrador concursal de decidir si con la concesión de una prórroga es suficiente para poder confeccionar el informe o si necesita además la ayuda de un auxiliar delegado.

\section{Expertos independientes}

$\mathrm{El}$ art. $83 \mathrm{LC}$ es el precepto que señala el mecanismo que tiene que utilizar la Administración Concursal en caso de que estime necesaria la ayuda de un experto independiente ${ }^{31}$. Lo primero que hará será elegir al profesional que mejor se adapte a lo que necesita para posteriormente proponer su nombramiento y los concretos términos del encargo al juez del concurso ${ }^{32}$.

La decisión del juez vendrá motivada en función de dos factores: si considera necesario el nombramiento o no según el tipo de encargo que se pretenda que este experto realice o si entiende que el profesional propuesto incurre o no en alguna de las causas de incapacidad, incompatibilidad y prohibiciones previstas legalmente. Este aspecto es fundamental por las especiales implicaciones que tienen las valoraciones que el referido profesional efectúe de cara a la posterior tramitación del procedimiento concursal.

Llegados a este punto nos preguntamos hasta dónde llega la facultad discrecional del juez para aceptar o no el nombramiento del experto independiente y la responsabilidad que el sentido de la decisión puede pro-

ocasionar situaciones absurdas en los supuestos de concursos que se tramiten bajo las reglas del procedimiento abreviado, ya que en estos casos la prórroga para realizar el informe no puede exceder de quince días (art. 191.2 LC), plazo en el que debe tramitarse la totalidad del proceso de contratación del auxiliar delegado (incluyendo la audiencia del administrador concursal), lo que puede provocar que cuando el profesional designado tome posesión de su cargo, la prórroga para la emisión del informe ya haya finalizado o esté a punto de hacerlo. Vid. A. I. BENITO DE LOS Mozos, «Los plazos en el procedimiento abreviado: comunicación de créditos y lista de acreedores», Revista La Ley Mercantil, núm. 16 (2015), pp. 4 y ss., quien señala que la LC tampoco prohíbe suspender el cómputo del plazo y que, aun no siendo una solución muy ortodoxa, existen algunos Juzgados de lo Mercantil que optan por esta práctica para salvar la necesidad de tener que nombrar obligatoriamente a un auxiliar delegado.

${ }^{31}$ La Ley regula todo lo relativo a los referidos expertos dentro de la sección referente al inventario de la masa activa.

32 Vid. C. Pastor Sempere, «Comentario al art. 83», en E. Gallego Sánchez (coord.), Ley Concursal. Comentarios, jurisprudencia y formularios, Madrid, La Ley, 2005, p. 962, quien puntualiza que la Ley no determina si se propondrá al juez la identidad del experto independiente ni si el juez puede actuar de oficio. 
vocar a la masa del concurso. Hay que tener en cuenta que, conforme al art. $83 \mathrm{LC}$, contra la decisión del juez no cabe recurso, es decir, que tanto aquella situación en la que el juez acuerde el nombramiento del experto independiente como aquella en la que decida que el referido nombramiento es improcedente no podrá ser rebatida ni por las partes del procedimiento ni por la Administración Concursal. La razón de que la Ley no permita el recurso contra esta decisión tenemos que buscarla en la agilidad que se le quiere dar al procedimiento concursal, evitando que cuestiones técnicas como éstas hagan retrasar la continuación del procedimiento.

Debe hacerse referencia al cambio de situación que se ha producido tras la reforma de la Ley en el año 2009. Antes de la referida reforma, y como veremos a continuación, la retribución de estos expertos independientes se satisfacía con cargo a la masa del concurso. Por esta razón, entre las circunstancias a valorar por el juez del concurso a la hora de decidir el nombramiento o no del experto que se le proponía influía también la retribución que iban a percibir éstos y la capacidad de la masa del concurso para hacer frente a dicho coste. Con la reforma del año 2009 esta circunstancia ya no es relevante en la decisión, puesto que esta retribución correrá a cargo de la propia Administración Concursal, teniendo que ser ésta y no el juez del concurso la que valore el coste que el nombramiento del experto tendrá para sus honorarios.

Al eliminarse esta situación, entendemos que la decisión del juez aceptando o no el nombramiento del experto independiente deberá fundamentarse única y exclusivamente en el hecho de si el profesional que se pretende nombrar incurre en alguna causa de incapacidad, incompatibilidad o prohibición, y no en otras circunstancias como la adecuación o no del nombramiento en función del tipo de procedimiento o del coste del mismo, puesto que ya no tiene que soportar la masa los gastos de estos profesionales, sino que es la Administración Concursal quien hará frente a ellos y quien en su caso deberá valorar si es o no procedente la contratación. De esta forma, la función del juez respecto al nombramiento de expertos independientes ha pasado a limitarse a un control de legalidad del nombramiento del profesional propuesto por la Administración Concursal.

Ello permite evitar además situaciones de responsabilidad de la Administración de Justicia en supuestos donde la Administración Concursal hubiese propuesto el nombramiento de un experto independiente y el juez del concurso hubiese declinado el referido nombramiento por entender que el mismo no era necesario para el concreto procedimiento concursal. En este estado de cosas, si se demuestra que como consecuencia 
de la falta de nombramiento de un profesional experto independiente se han generado una serie de daños y perjuicios a la masa del concurso, quien debería responder por los referidos daños sería la Administración de Justicia, puesto que la Administración Concursal advirtió previamente de la necesidad del nombramiento. Sin embargo, con este sistema, el juez se limita a controlar si el profesional nombrado no incurre en ninguna causa que le impida legalmente la designación, por lo que las hipotéticas responsabilidades que éste pudiera contraer durante el desarrollo de su labor serán encauzadas por la vía del art. 83.2 LC relativo a la responsabilidad de los expertos independientes. Respecto a la Administración Concursal, la responsabilidad de ésta vendrá determinada, como ya hemos destacado, por la elección del profesional (culpa in eligendo), por la responsabilidad en el control de la labor que el profesional nombrado desarrolla (culpa in vigilando) y por la responsabilidad en las directrices que se le dan (culpa in instruendo).

De igual forma, nada dice la Ley en cuanto a la posibilidad de que, rechazado el nombramiento de un determinado experto por parte del juez del concurso por incurrir éste en alguna de las causas tasadas recogidas en el art. 83.2 LC, la Administración Concursal pueda proponer otro distinto o realice cuantas solicitudes estime precisas para conseguir el nombramiento de un experto que entienda necesario. En este sentido, circunstancias no expresamente reguladas en la Ley como éstas deberían ser resueltas en el marco de la colaboración que debe existir entre juez y Administración Concursal, por lo que no parece que haya inconveniente en que la Administración Concursal pudiese dirigirse al juez cuantas veces fuese necesario para conseguir el nombramiento de un experto independiente.

Asimismo, el juez del concurso, en aspectos tan técnicos como éste, deberá intentar acceder a la pretensión de la Administración Concursal, pues es este órgano el que tiene una mayor información de la situación del deudor y quien mejor conoce las necesidades para la elaboración del informe. Por tanto, en la práctica, el juez debería intentar acceder siempre a lo solicitado por la Administración Concursal, sin perjuicio de que pueda en determinadas circunstancias impedir el nombramiento que se le propone por cuestiones relacionadas con el régimen de incapacidades, incompatibilidades, prohibiciones, recusación y responsabilidad que la propia norma prevé en el segundo apartado del art. $83 \mathrm{LC}$.

En lo relativo a la retribución de los expertos independientes, como hemos venido exponiendo se ha producido un cambio en el art. 83.3 LC, pasando de percibir sus honorarios con cargo a la masa del concurso a per- 
cibirlos con cargo a los honorarios de la Administración Concursal. Antes de la reforma del año 2009 los expertos independientes, una vez realizado su informe, giraban su minuta y la misma le era abonada con cargo a la masa del concurso. Esta situación ha cambiado radicalmente, puesto que a raíz de la reforma de 2009 la retribución de estos expertos corre a cargo de la Administración Concursal con todo lo que ello conlleva, es decir, que se elimina una de las diferencias que existían hasta el año 2009 entre expertos independientes y auxiliares delegados, la cual era la retribución con cargo a la masa que recibían los expertos independientes y la retribución con cargo a los honorarios de la Administración Concursal que recibían los auxiliares delegados, pasando a partir de la reforma del 2009 a ser retribuidos tanto unos como otros con cargo a los honorarios de la Administración Concur$\mathrm{sal}^{33}$. A pesar del cambio en la retribución, los expertos independientes siguen conservando las facultades que tenían.

Es importante no confundir al experto independiente con los auxiliares delegados. La principal diferencia entre los expertos independientes y los auxiliares delegados es precisamente su régimen de sometimiento, mientras que los primeros son completamente independientes, los segundos dependen de la Administración Concursal. La reforma de la Ley ha eliminado parte de esa independencia al haber pasado a depender económicamente los referidos expertos de la Administración Concursal, siendo ésta quien debe retribuir sus servicios.

De esta forma, la función de los expertos reside en valorar la masa activa del concursado, por lo que tendrá interés directo en que la referida valoración sea lo mayor posible, puesto que de ello depende la retribución de la Administración Concursal e indirectamente su propia retribución (se asegura que el administrador concursal que contrata sus servicios dispone de fondos suficientes para abonar sus honorarios, por lo que podrá verse en disposición de fijarlos en una mayor cuantía).

No obstante, antes de la reforma, a pesar de no depender económicamente de la Administración Concursal como lo hacen ahora, sí que dependían de hecho, por la simple razón de que la Administración Concursal elige a un experto independiente y no a otro con fundamento en un criterio de confianza, por tanto, con ello ya existía una relación de dependencia

33 P. J. Malagón Ruiz, «Estructura del informe e inventario de la masa activa», en P. Martín Molina (dir.), La reforma de la Ley Concursal analizada por especialistas, Madrid, Dykinson, 2012, p. 263, destaca el poco sentido que tiene que los honorarios de los expertos independientes sean fijados por el juez del concurso pero que los pague la Administración Concursal. 
(si se rompe el vínculo de confianza, la Administración Concursal no elegiría a ese experto independiente para la próxima vez).

En relación a ello, es innegable que esta nueva disposición acerca de la retribución de los referidos profesionales puede afectar el correcto funcionamiento del procedimiento concursal al existir el peligro de que la Administración Concursal prescinda de apoyarse en estos profesionales para no tener que retribuirlos ${ }^{34}$, con la merma que ello conllevaría de la calidad del informe de la Administración Concursal. De esta forma, el informe contendría valoraciones muy lejanas del valor real que determinados bienes y derechos tienen ${ }^{35}$, con el perjuicio que ello conllevaría a los acreedores del deudor ${ }^{36}$.

En conclusión, entendemos que no es una decisión correcta de política jurídica que la retribución de los expertos independientes se haga con cargo a los honorarios de la Administración Concursal ${ }^{37}$.

Debería haberse apostado en su caso por reformar el reglamento regulador del arancel de retribución de la Administración Concursal (RD 1860/2004) actuando sobre los porcentajes a percibir por las dife-

34 En igual sentido ibid., p. 264.

35 Vid. la práctica que recoge para la valoración de activos M. Cervera Martínez, «Determinación de la masa activa del concurso», en P. Prendes CarRIL y A. Muñóz PareDES (dirs.), Tratado judicial de la insolvencia, t. II, Cizur Menor, Thomson Reuters-Aranzadi, 2012, p. 1289.

${ }^{36}$ De hecho, esto ya está ocurriendo en la actualidad. Pensamos que esta práctica, en el actual marco de regulación de la composición de la Administración Concursal, debería dar lugar a algún tipo de responsabilidad, ya que no se está afrontando profesionalmente la tramitación del procedimiento cuando la Administración Concursal está compuesta por un único profesional que, careciendo de conocimientos jurídicos o económicos, afronta el desarrollo de una función tan importante como la de la confección del informe. El verdadero problema reside en que no se están exigiendo responsabilidades a los profesionales que realizan un trabajo tan importante como el informe de la Administración Concursal; informes que, en ocasiones, ante la falta de aptitud profesional de quien lo efectúa, no contienen más que conceptos genéricos y vacíos que para nada sirven, abocando al deudor a una liquidación irreversible que podría haber sido remediada de haberse apoyado en expertos.

37 La función de avalúo de los bienes incluidos en el inventario es una función esencial para el concurso y que obliga a contratar a profesionales de la tasación para que indiquen qué valor tiene un determinado bien. No debería abonar el administrador concursal este informe cuando el mismo es parte esencial y específica del propio concurso y él no ha sido nombrado para realizar esta función. Vid. en este sentido E. J. ETXARANDIo HERRERA, «La determinación de las masas del concurso», en Manual de Derecho Concursal, 2. ${ }^{a}$ ed., Madrid, La Ley, 2009, p. 623, quien señala que se ha desvanecido la fórmula de mejorar la calidad del inventario y reintegrar la masa activa con la recluta de profesionales de conocimientos en los que el administrador concursal no es experto. Destaca además el autor que si, aun existiendo masa líquida, ha de retirar de su remuneración el administrador concursal el precio de tales profesionales no es creíble que lo haga con abundancia. 
rentes tramitaciones del procedimiento, si se concibe la retribución de la Administración Concursal como muy alta. Sin embargo, es un error, lo que da cabida a la situación actual: que dos profesionales absolutamente distintos, independientes entre sí y con funciones diferentes - pese a que lógicamente colaboren en la realización del mismo informe- tengan que repartir sus honorarios. Si la Ley considera a los mismos como independientes, sus honorarios deben ser así, independientes los unos de los $\operatorname{otros}^{38}$. Con todo ello, la nueva situación lo que requiere es que la Administración Concursal sea prudente en la elección del experto independiente que le ayude, prudencia que el legislador se asegura siendo la Administración Concursal la que haga frente a la retribución de los profesionales que ésta contrate.

Por último, no se explica que el apartado 3 del art. 83 LC señale que el detalle de los honorarios de los expertos independientes se incorpore al inventario. Esta previsión podía tener sentido antes de la reforma, cuando la referida retribución era abonada por la masa del concurso, no en la situación actual en la que debe ser abonada, como hemos indicado, con cargo a los honorarios de la Administración Concursal. El detalle de la retribución de los expertos independientes debería venir pormenorizado, en su caso, dentro de los propios honorarios percibidos por la Administración Concursal en la partida correspondiente de los créditos contra la masa, pero no en el inventario de bienes y derechos del deudor. Además, no se prevé en la Ley que el detalle de los honorarios de los auxiliares delegados, aun siendo abonados también por la Administración Concursal, sean incorporados al inventario de bienes y derechos.

Por todo lo expuesto, concluimos que la reducción del número de administradores concursales ha traído en la práctica beneficios por la agilidad con la que la Administración Concursal desarrolla ahora su trabajo. Pero dado que la Administración Concursal debe actuar conforme a un parámetro de diligencia debida, ésta puede verse obligada a apoyarse en otros profesionales que complementen sus conocimientos para evitar que ello repercuta negativamente en la confección del informe.

\footnotetext{
38 Piénsese en una situación donde la Administración Concursal pudiese llegar a tener discrepancias con los informes emitidos por los expertos independientes nombrados y que a pesar de ello tenga que retribuirlos a su cargo.
} 


\section{ADMINISTRADOR CONCURSAL PERSONA JURÍDICA COMO SOLUCIÓN PARA INTEGRAR EXPERTOS JURÍDICOS Y ECONÓMICOS EN LA ADMINISTRACIÓN CONCURSAL QUE CUMPLAN CON EL PARÁMETRO DE DILIGENCIA EXIGIBLE EN LA ELABORACIÓN DEL INFORME}

En el intento de buscar la profesionalidad en el desarrollo de la elaboración del informe y para solucionar las deficiencias que el nombramiento de una Administración Concursal unipersonal puede en ocasiones tener, la Ley 38/2011, de Reforma Concursal, introdujo en nuestro ordenamiento la posibilidad de nombrar como administrador concursal una sociedad. Hasta entonces, y desde la entrada en vigor de la Ley del año 2003, la Administración Concursal siempre ha estado formada por profesionales personas físicas, sin perjuicio de que como tercer administrador concursal pudiese ser nombrado una persona jurídica, ya que para esta serie de concretos supuestos la Ley preveía originariamente en el art. 27 LC que se designara una persona física con las condiciones de profesionalidad de un economista. Por tanto, antes de la reforma de 2011, la composición trimembre de la Administración Concursal siempre era desempeñada por personas físicas (como hemos indicado: el profesional jurídico y el profesional económico en su propio nombre, y el administrador concursal profesional, que, según la redacción originaria de la Ley, debía ser un profesional económico, representante de una persona física o jurídica acreedora del concursado).

Como señalábamos, la reforma del año 2011 ha permitido que pueda ser designada como administrador concursal una persona jurídica. El sentido de que se introduzca esta posibilidad hay que buscarla en los beneficios que el hecho de permitir la participación conjunta de una serie de profesionales con la debida formación genera para el desarrollo del procedimiento concursal ${ }^{39}$. Por esta razón, el legislador ha buscado potenciar la creación de personas jurídicas que actúen como administradores concursales, fomentando su utilización con la introducción de una serie de ventajas respecto al administrador concursal persona física.

39 J. Quijano GonZÁLEZ, «La Administración Concursal», op. cit., p. 212, aboga por la utilización de las personas jurídicas como administrador concursal además de por el ahorro de costes que supone, también por el tratamiento jurídico que le dedica la propia reforma del año 2011. En igual sentido vid. L. MELERo BOSCH, «¿Hacia la societarización de la administración concursal?», RDCP, núm. 15 (2011), pp. 249-260. 
Destacamos la relativa a la limitación de la adjudicación de tres concursos en dos años a un mismo profesional, circunstancia que sólo opera para las personas físicas, no para las personas jurídicas, las cuales podrán ser nombradas en tantos concursos como se quiera a tenor del art. 28.2 LC. Este beneficio puede parecer lógico por la cantidad de recursos técnicos de los que dispone una sociedad integrada por una serie de profesionales a la hora de llevar varios procedimientos a la vez en comparación con un profesional persona física que actúa individualmente. No obstante, con la reforma se pierde la garantía competencial que ofrecía la limitación de concursos a todos los administradores concursales, ya que la excepción de esta limitación a favor de la persona jurídica hace patente el riesgo de que un mismo administrador concursal (sociedad) acapare el nombramiento en gran cantidad de procedimientos en detrimento del resto de profesionales que pueden optar también a ser administradores en los referidos procedimientos, ya sean personas físicas o personas jurídicas. Recordamos que la Ley hace referencia en el art. 27.4 LC a una recomendación al juez del concurso para que todos los profesionales que se encuentren inscritos en la lista de administradores concursales existentes en el decanato puedan acceder a procedimientos concursales, señalando el legislador que tendrá que abogarse por una distribución equitativa de las designaciones. Dado que el juez tiene la potestad de designar a unos concretos administradores concursales en detrimento de otros en previsión de que el procedimiento revista una especial complejidad, es ahí donde la persona jurídica muestra una mayor fortaleza, ya que para este tipo de complejos procedimientos, el juez puede considerar conveniente la designación de una persona jurídica donde se aglutina una organización de profesionales y de medios que podrán hacer frente a esta situación mejor que un administrador único persona física ${ }^{40}$.

${ }^{40}$ Es importante hacer referencia en sede de persona jurídica a aquella situación en la que un profesional persona física susceptible de ser elegido administrador concursal se encuentre incluido al mismo tiempo en la lista que se va a enviar al decanato como persona física y también como parte de una persona jurídica, aumentando de esta forma las posibilidades de acceder al nombramiento. La fórmula utilizada es sencilla: el administrador concursal persona física se incorpora a la lista de acreedores en su propio nombre. Posteriormente, se integra en el seno de una persona jurídica y accede nuevamente a la lista, apareciendo de esta forma en la misma como persona física y como integrante de una persona jurídica. Lógicamente estos profesionales tienen más posibilidades que el resto de ser elegidos como Administración Concursal (el doble), ya que pueden ser seleccionados directamente como persona física o a través de la sociedad de la que forman parte. Concebimos esta práctica como perjudicial y proponemos su erradicación, puesto que la existencia de una lista busca distribuir equitativamente los nombramientos (con la excepción de la deci- 
Para poder tener un completo conocimiento de la situación, debemos analizar los requisitos para poder ser designada una persona jurídica como administrador concursal:

1. Estar integrada por al menos un abogado y un economista. Éste es un requisito que parece muy elemental, pero que conviene aclararlo por las diferentes posibilidades a las que puede dar lugar. El precepto introduce la salvedad «al menos» por lo que entendemos que no existe inconveniente para que esta sociedad esté compuesta por más de un abogado y por más de un economista mientras que se cumpla con el mínimo de estos profesionales marcado por la Ley. Asimismo, el concepto «integrada» nos hace ver la amplitud que se pretende conceder, permitiendo todo tipo de vinculaciones con la sociedad nombrada administrador, ya sea por una mera relación contractual $u$ ostentando otras posiciones en el seno de la misma ${ }^{41}$.

Para el abogado que integre la sociedad se requiere la condición de que el mismo esté en ejercicio, por lo que se desecha la opción de los letrados no ejercientes, profesionales que pertenecen a un colegio de abogados correspondiente, pero que no se encuentran habilitados para la práctica de la profesión ante los tribunales.

2. Independencia y dedicación en el desarrollo de las funciones de Administración Concursal. No explica el legislador a qué se refiere con el concepto «independencia en el desarrollo de las funciones de Administración Concursal». Creemos que con ello hace referencia a que la persona

sión discrecional del juez en determinados casos) para que todos los profesionales que aparecen en la referida lista y que desean ser nombrados administrador concursal tengan iguales posibilidades de ser seleccionados. Desde el momento en que se permite que una persona física aparezca en la lista, además de en su propio nombre, como integrante de una persona jurídica, quiebra el sistema proporcional de designación y el fundamento de la existencia de la propia lista. Por esta razón, proponemos que los profesionales que quieran acceder a la lista de administradores concursales elijan entre hacerlo de forma individual como persona física o en el seno de una persona jurídica, siendo incompatible comparecer en una misma lista para un mismo juzgado de las dos formas a la vez.

${ }^{41}$ Surge la duda del tipo de relación que debe darse entre la persona jurídica administrador concursal y las personas físicas que en su caso la integren (por ejemplo, si es necesario que las personas que conforman la sociedad estén contratadas para que ésta cumpla con el concepto de «integración de profesionales económicos y jurídicos» o bastaría con que éstos profesionales estuviesen unidos a la sociedad por cualquier tipo de relación como, por ejemplo, por un contrato de colaboración mercantil). Desde aquí entendemos que es válida cualquier tipo de relación entre la sociedad designada administrador concursal y los profesionales que la integren mientras ésta pueda contar con los requisitos exigibles en el momento en el que es designada y durante el desarrollo de la totalidad del procedimiento concursal. De igual forma, nada impide que una sociedad que tuviese contratados a este tipo de profesionales se disuelva a la conclusión del procedimiento. 
jurídica que desarrolle las labores de Administración Concursal debe ser autónoma y ejercer esta función únicamente a través de la sociedad inscrita como elegible, huyendo de figuras como la participación en otras mercantiles cuyo objeto sea también el desempeño de funciones de Administración Concursal, apareciendo en la lista mediante diversas fórmulas o la participación en otras sociedades que la hagan de facto, dependiente de ellas. Entendemos, por tanto, que se refiere a independencia entendida como concepto global para la persona jurídica, la misma independencia que se exige a la persona física administrador concursal, e independencia entre sí de cada uno de los miembros que forman la misma ${ }^{42}$.

La última de las cuestiones que debe ponerse de manifiesto en lo relativo a la persona jurídica administradora concursal es aclarar si ésta debe adoptar un determinado tipo societario o no. La Exposición de Motivos de la Ley 38/2011 introduce a modo ejemplificativo un tipo societario sobre el que podría regularse la persona jurídica administrador concursal. Decimos que a modo ejemplificativo, ya que el texto literal de este preámbulo parece que deja abierta la creación de sociedades de otra naturaleza jurídica («en tanto que algunas de sus formas, como es la sociedad profesional»). En función de ello, existen autores que entienden que la persona jurídica administrador concursal tiene que encuadrarse única y exclusivamente bajo el tipo de la sociedad profesional ${ }^{43}$, y otros autores que creen

${ }^{42}$ C. Romero SANZ DE MADRID, «Los órganos del concurso», op. cit., p. 106, señala que es sumamente difícil que profesionales que trabajan en la misma persona jurídica designada sean independientes entre sí.

${ }^{43}$ Vid. M. J. Guerrero LeBrón, «Sociedades. Contradicción entre dos artículos estatutarios. Designación de representante persona física de la sociedad administradora. Denegación de nota simple literal. Escritura de renuncia al cargo de liquidador. Administrador concursal persona jurídica. Acuerdo de sometimiento a mediación y arbitraje de los conflictos entre administradores», RDN, núm. 271 (2013), p. 53, quien al respecto señala que tras el análisis del texto articulado de la Ley Concursal se concluye que el legislador ha determinado que sean las sociedades profesionales las únicas personas jurídicas que puedan ejercer el cargo de administrador concursal. Continúa sosteniendo la autora que tal afirmación puede realizarse tras la lectura sistemática de muchos de sus preceptos y, particularmente, de la Exposición de Motivos de la Ley 38/2011, de 10 de octubre, de reforma de la Ley 22/2003, de 9 de julio, Concursal. Por último, Guerrero Lebrón añade: «En definitiva, si se exige el carácter profesional de la persona jurídica que ejercite el cargo de administrador concursal es porque la sociedad debe ser el centro subjetivo de imputación de los actos que conlleven su ejercicio, atribuyéndole los derechos y obligaciones que nacen del mismo y desarrollados directamente bajo su razón o denominación social: la sociedad tiene que estar colegiada, la sociedad debe responder del ejercicio del cargo, contratar el seguro de responsabilidad civil, estar sujeta al régimen de incompatibilidades y prohibiciones, etc. Siendo así, se entiende que no sea posible el ejercicio del cargo por medio de otras opciones sociales que no impli- 
que además de este tipo societario puede haber otros que cumplan también con los requisitos necesarios para ser administrador concursal ${ }^{44}$. De igual forma, no podemos dejar de señalar las conclusiones a las que llegaron una serie de magistrados de los Juzgados de lo Mercantil de Madrid a favor de la exclusividad de la sociedad profesional en este aspecto ${ }^{45}$.

En nuestra opinión, la Exposición de Motivos deja claro que no pretende que las personas jurídicas administrador concursal sean exclusivamente las sociedades profesionales, puesto que su redacción deja abierta la posibilidad a otro tipo de sociedades, señalando únicamente de forma ejemplificativa el tipo de la sociedad profesional, probablemente porque es el que más se ajusta al perfil que busca la Ley, pero en ningún caso lo hace de forma exclusiva ${ }^{46}$.

Nada obsta, por tanto, para poder utilizar también otros tipos societarios. Para buscar alternativas debemos partir de los requisitos que necesariamente tiene que cumplir la sociedad para poder ser administrador

quen dichas circunstancias, como ocurre con las sociedades de medios, las de comunicación de ganancias y las de intermediación».

${ }^{44}$ Vid. A. Sánchez Magro, «Comentario al art. 27», en E. López López y A. Macías Castillo (coords.), Comentario práctico a la nueva Ley Concursal, Madrid, La Ley, 2012, p. 203, quien destaca que la redacción de la Ley es abierta al no constreñir la persona jurídica administradora concursal a una forma específica, posibilitando una interpretación literal que permita la designación de cualquier persona jurídica que integre profesionales jurídicos y económicos.

45 A consecuencia de la reforma de la Ley Concursal del año 2011, once de los doce jueces de lo mercantil de la capital madrileña se reunieron en fecha 13 de diciembre de 2011 para coordinar criterios interpretativos en torno a algunas de las cuestiones más problemáticas de la reforma; acuerdos que no son ni mucho menos vinculantes, pero que constituyen una antesala de lo que posteriormente se plasmará en las sentencias de estos juzgados. En este sentido, estos magistrados llegaron a la conclusión de que las personas jurídicas que se postulen como administradores concursales tienen que constituirse como sociedades profesionales por ser estas sociedades las que guardan mayor coherencia con la profesionalidad, rigor y responsabilidad propia del ejercicio del cargo de administrador concursal. Añaden que hay que entender que cuando la Ley Concursal ha empleado la expresión «persona jurídica» ha utilizado tal término genérico porque precisamente la sociedad profesional no es un tipo societario concreto, sino una clase que puede englobar bajo sus previsiones distintos tipos sociales de los existentes en la legalidad de la sociedad. Respecto a ello, A. SÁnCHEZ MAGRO, «Sociedades de administración concursal y auxiliares delegados», en P. MARTín Molina (dir.), La reforma de la Ley Concursal analizada por especialistas, Madrid, Dykinson, 2012, pp. 122 y 123, manifiesta que las consideraciones de los jueces en el encuentro de fecha 13 de diciembre de 2011 chocan con la relación abierta de la Ley.

${ }^{46}$ En igual sentido vid. L. González-SERrano CAZORLA, «El administrador concursal persona jurídica: su naturaleza jurídica en la Ley 38/2011», RDCP, núm. 17 (2012), p. 145, quien precisa sobre este particular que la interpretación literal del término conforme a la interpretación normativa que señala el art. 3.1 CC no ofrece dudas al respecto, ya que nada se dice de sociedad profesional. 
concursal: la integración de los dos profesionales mencionados y la independencia y dedicación en sus funciones, para posteriormente incardinarlos en un modelo societario. Por tanto, nada impide que cualquier tipo de sociedad en el que se integren una serie de profesionales bajo una colaboración, siempre que estos profesionales sean al menos un letrado en ejercicio y un economista, y que garantice la debida independencia en sus funciones, pueda ser administrador concursal persona jurídica. Que el tipo societario que mejor se adapte a lo que exige la Ley sea la sociedad profesional no quiere decir que no pueda designarse administrador concursal persona jurídica bajo otro modelo organizativo, siempre que se cumpla con los requisitos tasados en el art. $27 \mathrm{LC}^{47}$.

Además, las exigencias de la Ley tampoco se corresponden exactamente con los elementos definidores de las sociedades profesionales recogidos en la Ley 2/2007, de 15 de marzo, que regula este tipo societario, una prueba más que nos lleva a la conclusión de que el legislador no piensa únicamente en la figura de las sociedades profesionales. Sí que es cierto que la exigencia al administrador concursal designado de la suscripción de un seguro de responsabilidad civil por el art. 29.1 LC y el hecho de que el administrador concursal persona jurídica sea quien venga obligado a hacer frente al referido seguro se corresponde con el art. 11.3 de la Ley 2/2007,

47 Cualquier sociedad regulada en la Ley de Sociedades de Capital puede desarrollar la función de Administración Concursal. Nada impide que el objeto social de una sociedad de responsabilidad anónima o limitada sea prestar servicios jurídico-económicos en procedimientos concursales siempre que cumpla con las exigencias del art. 27 LC. En sentido contrario se muestra la Resolución de la Dirección General de los Registros y del Notariado (en adelante, DGRN) de 20 de junio de 2013; resolución que apoyándose en la STS (Sala 1. ${ }^{a}$ ) de 18 de julio de 2012 (rec. núm. 1198/2009) argumenta que «dado que los derechos y obligaciones de la Administración Concursal se imputan a la persona jurídica y que la Ley Concursal exige que las personas que integren la referida sociedad sean profesionales perfectamente identificados, no puede ser inscrita en el Registro Mercantil una sociedad que tenga como objeto la de prestar servicios de Administración Concursal si no es bajo la forma de sociedad profesional». Nos mostramos disconformes con la referida resolución por cuanto entendemos que el criterio de base tomado como referencia bajo el que se construye la argumentación es erróneo, ya que se parte de que la única sociedad que puede tener perfectamente identificados a los miembros que la forman es la sociedad profesional. Pensamos que ello es erróneo por cuanto no vemos inconveniente en que una sociedad como puede ser una sociedad anónima integre en su seno a profesionales que cumplan con las exigencias del legislador concursal, se identifique específicamente a los mismos para cada procedimiento concursal y presten el servicio igual que lo haría otra sociedad, sea cual sea la forma organizativa que permita integrar a sus miembros. Debe recordarse que la sociedad no tiene por objeto el ejercicio de una actividad para la que se requiera una titulación profesional (ya que el cargo de Administración Concursal no es una titulación), sino que la sociedad lo que hace es prestar unos servicios a través de unos profesionales cuya pertenencia a la referida sociedad faculta a la misma para ser seleccionada. 
de Sociedades Profesionales, precepto que ya señala la exigencia de un seguro que cubra la responsabilidad en la que pueda incurrir la sociedad profesional en el ejercicio de su actividad, pero ello no es suficiente para determinar la exclusividad de este tipo societario.

Podemos concluir, por tanto, que la Ley no se refiere exclusivamente a las sociedades profesionales como tipo de organización societaria en que se incardine el administrador concursal único persona jurídica, si bien este modelo organizativo es ciertamente el que mejor puede adaptarse a lo que el legislador pretende ${ }^{48}$.

En virtud de todo ello, creemos que la sociedad profesional no es exclusivamente el único tipo societario que puede desarrollar la función encomendada por el legislador a las personas jurídicas, si bien compartimos la idea de que es la mejor forma para lograrlo. Eso sí, con ello no estamos apostando por la elección preferente de una persona jurídica como Administración Concursal, por cuanto entendemos que el administrador concursal persona física puede seguir desarrollando la tarea de Administración Concursal única con las mismas garantías y profesionalidad que lo hace una persona jurídica.

${ }^{48}$ Esta forma societaria que, como hemos señalado, se encuentra regulada al amparo de la Ley 2/2007, de 15 de marzo, de Sociedades Profesionales, es la que mejor refleja lo que busca el legislador por las siguientes razones:

1. Integra no sólo a simples profesionales, sino a profesionales colegiados; hecho muy relevante para el caso que nos ocupa, ya que el art. 27 LC exige para el caso del letrado tener una experiencia de cinco años de ejercicio; ejercicio que en la actualidad sólo puede realizarse con el requisito previo de la colegiación obligatoria (art. 1 de la Ley 2/2007).

2. Es una sociedad multidisciplinar por cuanto integra en su seno a profesionales de dos ramas bien diferenciadas (letrados y economistas) que van a actuar de cara a un fin común. Ello se corresponde con el art. 3 de la Ley 2/2007 que señala expresamente esta característica.

3. Se produce una imputación de la actividad profesional a la propia sociedad constituida como ente en el art. 5 de la Ley de Sociedades Profesionales; hecho fundamental, puesto que el administrador concursal va a ser la propia sociedad y será ésta el sujeto sobre el que va a girar la actividad que normalmente realiza el administrador concursal único.

4. Este tipo social garantiza profesionalidad, rigor y responsabilidad; circunstancias propias del ejercicio del cargo de administrador concursal (arts. 9 y 11 de la Ley de Sociedades Profesionales).

5. La seguridad de que quien esté desarrollando las labores de administrador concursal dentro de la sociedad va a seguir perteneciendo a ella en virtud de la intransmisibilidad de la condición de socio profesional que señala el art. 12 de la Ley 2/2007. 


\section{LA RELACIÓN DE LA ADMINISTRACIÓN CONCURSAL Y EL DEUDOR PARA CUMPLIR CON LA DILIGENCIA DEBIDA EN LA ELABORACIÓN DEL INFORME}

La Administración Concursal, para poder cumplir con su trabajo, necesita de la colaboración de las partes; por ello, el legislador, consciente de la importancia de esta colaboración, refuerza la posición de la Administración Concursal recogiendo expresamente en la Ley esta exigencia (art. 42 LC).

El deber de colaboración con la Administración Concursal tiene que venir tanto de los acreedores como del propio deudor ${ }^{49}$. Nos encontramos ante el traslado a la legislación concursal del deber general de colaboración con la Administración de Justicia que se establece en los arts. 118 CE y 17 LOPJ. El hecho de que se regule expresamente en la Ley Concursal la obligación del deudor de colaboración con la Administración Concursal responde evidentemente a que es el patrimonio del deudor el que se va a ver intervenido, por lo que la Administración Concursal necesita el suministro de gran cantidad de información para poder cumplir con el mandato que tiene encomendado. Particularmente, para la confección del informe necesitará información de todo tipo (contable, jurídica, comercial...), por lo que es probablemente durante los dos meses de los que dispone para la elaboración del informe cuando la relación entre el concursado y el administrador concursal debería ser más intensa.

Este deber de información pretende ir más allá del deber que tiene el deudor de proporcionar a la Administración Concursal una serie de documentación esencial para que ésta pueda comenzar a trabajar. Nos referimos a lo regulado en el art. 6 LC en los supuestos de concursos solicitados por el deudor. No olvidemos que aunque la Administración Concursal disponga de la referida documentación, puede necesitar documentación diferente o aclaraciones respecto a lo ya proporcionado, con respeto, eso sí, a los límites legales ${ }^{50}$.

${ }^{49}$ Nos parece interesante destacar con carácter previo lo expuesto por el profesor TiRADO, quien señala que para analizar las relaciones de la Administración Concursal con el deudor y los acreedores debe partirse de una realidad que ambas partes comparten: «al actuar en el concurso procuran, exclusivamente, su propio interés». Vid. I. TIRADO, Los administradores..., op. cit., p. 353.

${ }_{50}$ Estos límites pueden venir dados, por ejemplo, por el hecho de que la revelación de la información suponga un atentado contra un derecho fundamental. MARTínEZ FLóREZ lo trata 
Una de las manifestaciones más importantes del incumplimiento del deber de colaboración del deudor con la Administración Concursal se materializa cuando éste facilita documentación falsa o errónea a sabiendas de esta circunstancia. En este sentido, debe estudiarse la responsabilidad que podría llegar a tener la Administración Concursal cuando manejase datos erróneos suministrados por el propio concursado ${ }^{51}$. La diligencia exigible a la Administración Concursal en este aspecto no puede ser otra que la de analizar los datos existentes y comprobar que se corresponden con la documentación que se le ha proporcionado ${ }^{52}$. Por esta razón, no puede dar credibilidad a todo cuanto le comunica el deudor ${ }^{53}$, sino que su diligencia le exige constatar cuanto se le facilita con la información de la que dispone, razón por la que si el deudor incumple este deber de colaboración a través de documentación falsa, la diligencia de la Administración Concursal debe llevar a ésta a poder constatar la referida circunstancia apoyándose en la documentación a la que ha podido tener acceso. Todo ello sin perjuicio de la responsabilidad que tendría el deudor en la sección de calificación del concurso, ya que el art. 164 LC prevé expresamente en su apartado 2.2. ${ }^{\circ}$ la calificación del concurso como culpable cuando el deudor hubiera cometido inexactitud grave en cualquiera de los documentos acompañados a la solicitud de declaración de concurso o

de forma detallada en A. Martínez Flórez, «Comentario al art. 42», en A. Rojo y E. Beltrán (coords.), Comentario de la Ley Concursal, t. I, Madrid, Civitas, 2004, pp. 875 y ss.

${ }^{51}$ Piénsese en el supuesto de que entre la documentación proporcionada por el deudor se encontrasen facturas falsas que hiciesen creer a la Administración Concursal que un determinado crédito comunicado al concurso ya había sido satisfecho a su legítimo acreedor.

${ }_{52}$ Nos remitimos en este aspecto a la labor verificadora de la Administración Concursal que expondremos a continuación.

53 Vid. A. Veiga Copo, «La comunicación de créditos», en La masa pasiva del concurso de acreedores, 2. ${ }^{\text {a }}$ ed., Cizur Menor, Civitas-Thomson Reuters, 2012, pp. 147 y 148, quien señala que la valoración que debe hacerse de la documentación proporcionada por el deudor ha de tomarse con cautela debido a la escasa credibilidad que puede tener una lista realizada motu proprio por el deudor. Continúa señalando que la información proporcionada por el deudor suele obedecer a ratios y valoraciones subjetivas del propio deudor, y que psicológicamente el concursado es más propenso a enmascarar su situación patrimonial que a reconocer la verdadera entidad de su fracaso empresarial en un desmesurado y correoso afán por huir hacia adelante. No debe olvidarse, nos dice el autor, que como complemento de los efectos patrimoniales que la declaración del concurso irroga, también impone al concursado el deber de colaborar e informar. El juez, al igual que los administradores del concurso, puede exigir la información que sea necesaria y conveniente para el interés del concurso, un deber sólo exigible por éstos, no por los acreedores. A ello ha de unirse la imposición del deber específico de puesta a disposición de la Administración Concursal de no toda, pero sí de determinada documentación y libros de la empresa. 
presentados durante la tramitación del procedimiento, o hubiera acompañado o presentado documentos falsos ${ }^{54}$.

También puede producirse aquella situación en la que el deudor ni siquiera entregue la documentación necesaria a la Administración Concursal, lo que podría dar lugar a una causa que provocase la declaración del concurso como culpable, ya que el art. 165 LC señala expresamente que el incumplimiento del deber de colaboración con la Administración Concursal constituye una presunción de existencia de dolo o culpa grave, elementos cuya concurrencia conllevan la calificación del concurso como culpable a tenor del art. 164 LC $^{55}$. En todo caso, el parámetro de diligencia debida de la Administración Concursal es el mismo aunque no se le facilite documentación, puesto que deberá confeccionar el informe con la información a la que pueda acceder, sin perjuicio de las responsabilidades en las que incurra el deudor ${ }^{56}$.

Por último, debe señalarse que este deber de colaboración del deudor se mantiene vigente hasta la total conclusión del procedimiento, sea cual sea la solución del mismo ${ }^{57}$, y que su observancia es muy importante también de cara al posible beneficio de exoneración del pasivo insatisfecho ${ }^{58}$.

${ }^{54}$ No debe confundirse que la documentación proporcionada por el deudor sea falsa con que la misma utilice conceptos poco fiables o interesados. De igual forma, tampoco debe asimilarse el término inexactitud al de discrepancia respecto a la valoración jurídica de los hechos. Vid. SJMer de Barcelona núm. 3, de 18 de febrero de 2008 (proc. 515/2005).

55 Vid. SAP Barcelona (Sección 15. ${ }^{a}$ ) de 3 de septiembre de 2008 (rec. núm. 42/2008), donde se confirma en grado de apelación la sentencia que acuerda calificar un concurso como culpable por falta de colaboración con la Administración Concursal.

56 En este sentido existe un debate jurisprudencial a la hora de calificar esta presunción de dolo o culpa grave entre las Audiencias de nuestro país, particularmente entre las Audiencias Provinciales de Barcelona y Madrid, con los pronunciamientos de cada una de sus dos secciones por antonomasia (secciónes $15 .^{\mathrm{a}}$ y $28 .^{\mathrm{a}}$, respectivamente); debate en el que no vamos a entrar por exceder del objetivo del presente trabajo pero cuyas principales líneas exponemos seguidamente. La Audiencia Provincial madrileña mantiene que lo único que presume este art. $165 \mathrm{LC}$ es la culpa y que posteriormente en un segundo estadio deberá comprobarse si existe una relación de causalidad entre la referida culpa y la situación de insolvencia para poder calificar el concurso como culpable [SAP Madrid (Sección 28.a) de 17 de julio de 2008 (rec. núm. 203/2007), o de 17 de marzo de 2009 (rec. núm. 304/2008)]. Sin embargo, la Audiencia Provincial barcelonesa cree que con esta presunción es suficiente para acreditar la culpabilidad del concurso [SAP Barcelona (Sección $15 .{ }^{a}$ ) de 16 de septiembre de 2008 (rec. núm. 388/2008)].

57 En este sentido vid. J. L. Colino Mediavilla, «Los efectos de la declaración del concurso», en J. Pulgar EzQuerRa (dir.), El concurso de acreedores, Madrid, La Ley, 2012, p. 249.

${ }^{58}$ Uno de los requisitos para que el deudor pueda acogerse a este beneficio es no haber incumplido las obligaciones de colaboración señaladas en el art. 42 LC según lo establecido por el RDL 1/2015, de 27 de febrero, sobre mecanismo de segunda oportunidad, reduc- 


\section{LA LABOR VERIFICADORA DE LA ADMINISTRACIÓN CONCURSAL}

Tal y como hemos venido desarrollando en el ejercicio de las tareas inherentes al cargo de Administración Concursal, ésta tiene que realizar las mismas conforme al parámetro de diligencia debida que rige su actuación. Esta diligencia requiere que el órgano técnico concursal tenga un conocimiento completo de toda la documentación relativa a la situación patrimonial del deudor. De esta forma, la Administración Concursal debe tener en cuenta no sólo aquello que se le dice o se le demanda, sino que debe constatar todo aquello que se le pone de referencia con la documentación del deudor a la que ha podido tener acceso, para de esta manera poder formar un juicio completo entre lo que dice el acreedor y lo que arroja la documentación del deudor. Como decimos, la diligencia debida a la hora de confeccionar el informe y los documentos anexos a éste exige de la Administración Concursal un conocimiento amplio de la situación patrimonial del deudor, lo que conlleva que no pueda mostrarse ajena a la información de la que dispone, sino que tiene que poner en relación la referida información con la que ahora obtiene por parte del acreedor. Ello le permitirá decidir con elementos valorativos si accede o no a lo que se le demanda, ejercitando una completa labor verificadora de toda la documentación a la que tiene acceso.

Esta labor tiene especial conexión con el parámetro de diligencia debida en cada una de las distintas partes que componen el informe, ya que el informe de la Administración Concursal está compuesto por diferentes partes enlazadas entre sí. Se le exigirá la diligencia debida de un auditor de cuentas en aquellas partes del informe que deban ser auditadas, la diligencia de un perito en aquellas partes que exijan una valoración pericial y la diligencia de un letrado en aquellas partes del informe que exijan un análisis jurídico.

La referida labor verificadora se pone de especial relieve en la función de reconocimiento de créditos. En esta situación, la Administración Concursal deberá examinar cada crédito comunicado, su fecha de nacimiento, analizar el título que lo documente, buscar su correspondencia en la contabilidad del deudor, estudiar si ha podido haber algún pago parcial a cuen-

ción de carga financiera y otras medidas de orden social, que ha modificado parte de la Ley Concursal en este sentido. 
ta del crédito que se comunica o algún tipo de compensación, y, finalmente, incluirlo en la lista de acreedores. En relación a ello no podemos olvidar que la carga probatoria recae en el acreedor, que es quien tiene que justificar el título en que basa su crédito y la calificación que pretende. Ahora bien, una vez que el referido acreedor ha cumplido con su carga probatoria, ya es tarea de la Administración Concursal indagar en la documentación del deudor para cerciorarse de si la realidad es la que se le expone o existe otra diferente. Sólo si la Administración Concursal cumple esta función correctamente estará actuando en interés del concurso ${ }^{59}$.

59 Vid. M. Aguilar Rubio, «La comunicación del crédito de la Hacienda Pública y su reconocimiento en el procedimiento concursal», en Crédito tributario y concurso de acreedores, Madrid, La Ley, 2009, p. 531, donde se destaca que el crédito tributario debe someterse a la verificación por parte de la Administración Concursal sin que ello implique que ésta asuma la potestad de la autotutela declarativa. 